\title{
Methane Steam Reforming on Supported Nickel, Effect of Nickel Content for Product Hydrogen
}

\author{
Akila Belhadi1 ${ }^{*}$, Souhila Boumaza1, Amar Djadoun², Mohamed Trari ${ }^{3}$, Ouiza Cherifi ${ }^{1}$ \\ ${ }^{1}$ Laboratory of Chemistry of Natural Gas, Faculty of Chemistry, USTHB, Algiers, Algeria \\ ${ }^{2}$ Department of Géologie FSTGAT, USTHB, Algiers, Algeria \\ ${ }^{3}$ Laboratory of Storage and Valorization of Renewable Energies, Faculty of Chemistry (USTHB), Algiers, Algeria \\ Email: "sarakila@yahoo.fr
}

Received 6 March 2016; accepted 2 May 2016; published 5 May 2016

Copyright (C) 2016 by authors and Scientific Research Publishing Inc.

This work is licensed under the Creative Commons Attribution International License (CC BY).

http://creativecommons.org/licenses/by/4.0/

(c) (i) Open Access

\begin{abstract}
The steam reforming of methane over $\mathrm{NiO} / \mathrm{ZnO}$ mixed oxides with different nickel contents was studied. Solids to $\mathrm{x} \% \mathrm{Ni} / \mathrm{ZnO}(\mathrm{x}=4$ and $10 \%)$ were deposited on $\mathrm{ZnO}$ by impregnation from nickel nitrate solution; after vaporization the solid is calcined at $500^{\circ} \mathrm{C}$ for $6 \mathrm{~h}$. The catalysts were characterized by X-ray diffraction (XRD) and BET method, scanning electron microscopy (SEM) and temperature programmed reduction (TPR). The XRD patterns revealed the NiO phase for all calcined catalysts. The chemical analysis confirmed the theoretical values of nickel. The catalysts were pre-treated under hydrogen at $500^{\circ} \mathrm{C}$ in situ, overnight before testing for the steam reforming of methane reaction $\left(\mathrm{CH}_{4} / \mathrm{H}_{2} \mathrm{O} / \mathrm{Ar}=10 / 10 / 80\right)$ in the temperature range $\left(475^{\circ} \mathrm{C}-650^{\circ} \mathrm{C}\right)$ under atmospheric pressure. The activities of both catalysts were investigated in a fixed-bed reactor for the Methane Steam Reforming (MSR) reaction. Globally, it was shown that the catalyst $10 \%$ nickel content has an important effect on the catalytic performances of solids i.e. the better results of hydrogen production were obtained with $10 \% \mathrm{wt}$. Ni/ZnO $\left(28 \times 10^{-3} \mathrm{~mol} / \mathrm{g}\right.$ catalyst $)$.
\end{abstract}

\section{Keywords}

Nickel Catalysts, ZnO, Methane Steam Reforming, Hydrogen

\section{Introduction}

For many years, the methane steam reforming (MSR) has been a leading technology for the generation of hydrogen in the refining and petrochemical complexes. MSR reaction is currently the dominant way used to obtain

*Corresponding author.

How to cite this paper: Belhadi, A., Boumaza, S., Djadoun, A., Trari, M. and Cherifi, O. (2016) Methane Steam Reforming on Supported Nickel, Effect of Nickel Content for Product Hydrogen. Open Journal of Physical Chemistry, 6, 34-41. 
syngas $\left(\mathrm{H}_{2}+\mathrm{CO}\right)$. The natural gas is the cleanest of all fossil fuels and MSR is a well-established process for the production of syngas and hydrogen [1]. In this respect, numerous supported catalysts have been tested, especially nickel and noble metal based catalysts, which have been found to exhibit promising catalytic performance [2]. Studies were carried out on the methane conversion, which focus on mainly two processes: direct and indirect conversion of methane. Furthermore, methane reforming at high temperatures results in the formation of carbon deposition via the decomposition of products with consequently a decrease of the energy efficiency [3] [4]. Hydrogen will have an important role in the future world economy scenario as a clean, renewable, and efficient fuel. It has been widely used in the petro-chemical processes like hydro-desulfurization, hydro-cracking, hydro-refining and so on. Nowadays, hydrogen becomes more and more involved as the feedstock in the synthesis of methanol/dimethyl ether (DME), and particularly, in the Fischer-Tropsch reaction to make liquid fuels from coal or natural gas. Besides, hydrogen is ideal for fuel cells, e.g., for proton exchange membrane (PEM) fuel cell [5] [6]. Therefore, it is not only an important chemical feedstock, but also a clean energy carrier. Accordingly, the demand for low-cost hydrogen would be always predominant either for the mass production or for distributed applications. However, hydrogen is known as an energy carrier, which must be produced from other primary energy sources. Its production from hydrocarbons, especially methane, i.e., the principal constituent of natural gas, can be performed by mainly three ways: steam reforming, partial oxidation and auto thermal reforming [7]. It is acknowledged that the MSR is the most economical method for hydrogen production among the current commercial processes.

Supported nickel catalysts as heterogeneous catalysts have attracted a great attention because of their potential applications in the petrochemical industry such as hydrogenation, deoxygenation, methanation, reforming and hydrocracking. Besides good nickel particle dispersion in the catalyst support, the pore size is a crucial variable affecting the catalyst performance since the activity usually relies on the presence of accessible active centres located in the internal pore of the catalysts [8] [9]. Larger-pore sizes of the catalyst provide a better diffusion of reactants and products during the course of reaction [10]. Therefore, high dispersion of small particles of nickel and the large porosity of the catalyst are desirable. The catalyst support may play a more active role by increasing the dispersion and stability of metal particles.

During the reaction between methane and NiO-based oxides, the syngas yield depends on the oxidation degree of the oxygen carriers: highly oxidized oxide particles resulted in the formation of $\mathrm{CO}_{2}$ and $\mathrm{H}_{2} \mathrm{O}$, while reduced particles favour the production of $\mathrm{CO}$ and $\mathrm{H}_{2}$ [10]. The MSR reaction takes place through the dissociation of methane adsorbed onto the metallic Ni-sites and the dissociation of water adsorbed at the metal - support interface to produce $\mathrm{CO}$ and $\mathrm{H}_{2}[11]$ [12].

A major challenge is that $\mathrm{Ni}$ catalysts possess a great thermodynamic potential for coke formation during reforming reactions, and several methods are discussed to synthesize coke resistant Ni catalysts [10] [13].

In this work we have studied the reactivity of catalysts $\mathrm{NiO} / \mathrm{ZnO}$ at two $\mathrm{Ni}$ percentages $\mathrm{x} \% \mathrm{Ni} / \mathrm{ZnO}(\mathrm{x}=4$ and $10 \%)$ in the reaction $\left(\mathrm{CH}_{4}+\mathrm{H}_{2} \mathrm{O}\right)$. The catalysts were characterized in the calcined state by atomic absorption BET method, X-ray diffraction (XRD), scanning electron microscopy (SEM) and temperature programmed reduction (TPR).

\section{Experimental}

\subsection{Sample Preparation}

The solids $\mathrm{NiO} / \mathrm{ZnO}\left(\mathrm{ZnO}\right.$ (Kadox) were prepared by impregnation of $\mathrm{ZnO}$ support with $\mathrm{x} \% \mathrm{Ni}\left(\mathrm{NO}_{3}\right)_{2}, 6 \mathrm{H}_{2} \mathrm{O}(1$ M) (Merck) ( $\mathrm{x}=4$ and 10\%) [14]. The solution was stirred during $2 \mathrm{~h}$, and evaporated at $80^{\circ} \mathrm{C}$ under agitation. The solid was dried overnight, calcined at $300^{\circ} \mathrm{C}(2 \mathrm{~h})$ and $500^{\circ} \mathrm{C}(6 \mathrm{~h})$ at a heating rate of $4^{\circ} \mathrm{C} / \mathrm{mn}$ in air flow $\left(1.2 \mathrm{~L} \cdot \mathrm{h}^{-1}\right)$. The catalysts were sieved to have a particle diameter less than $0.16 \mathrm{~mm}$.

\subsection{Catalysts Characterization}

The solids were analyzed by atomic absorption with a Perkin-Elmer $1100 \mathrm{~B}$ spectrometer. The specific surface areas were determined by the BET method using an analyzer of surface type (Coultronics 2100E). The crystalline structures were identified by X-ray diffraction (XRD) using a diffractometer ( $\theta / 2 \theta \mathrm{CGF})$ provided with a proportional detector and using $\mathrm{K} \alpha$ molybdenum anticathode $(\lambda=0.70930 \AA)$. The patterns were obtained for $2 \theta$ 
values ranging from $20^{\circ}$ to $70^{\circ}$ with a step size of $0.02^{\circ}$. The average crystallite size of the particles was calculated from the formula $(\mathrm{L}=0.9 \lambda / \beta \cos \theta)$, where $\beta$ is the width of the full width at half-height. The morphology of composite particles was observed By SEM (JEOL JSM-118 6360-LV). TPR was conducted on a U-shaped quartz tube embedded in a programmable furnace. $100 \mathrm{mg}$ of the catalyst was pre-treated under pure He flow at $500^{\circ} \mathrm{C}$ for $1 \mathrm{~h}$. The reducibility of the catalyst $4 \% \mathrm{Ni} / \mathrm{ZnO}$ at (TPR) was realized under hydrogen diluted in argon $(5 \%)$ with a heating rate of $5^{\circ} \mathrm{C} / \mathrm{min}$ in the range $\left(25^{\circ} \mathrm{C}-600^{\circ} \mathrm{C}\right)$, the TPR patterns were obtained by using a recorder connected to a GC equipped with TCD, the $\mathrm{H}_{2}$ consumption is recorded during the test and quantified after calibration. and then reduced under a gas mixture flow $\left(5 \% \mathrm{H}_{2}, 95 \% \mathrm{Ar}, 50 \mathrm{~mL} / \mathrm{min}\right)$

\subsection{Catalytic Reaction Test}

The catalyst was introduced in a fixed-bed quartz reactor placed within a tubular furnace, equipped with a programmed controller under atmospheric pressure. The bed temperature was monitored by a chromel-alumel thermocouple. $100 \mathrm{mg}$ of catalyst were activated in situ under $\mathrm{H}_{2}$ atmosphere at $500^{\circ} \mathrm{C} / 12 \mathrm{~h}$ and tested between $450^{\circ} \mathrm{C}$ and $600^{\circ} \mathrm{C}$. The reactant gas mixture $\left(\mathrm{H}_{2} \mathrm{O} / \mathrm{CH}_{4}=3.3\right)$ was achieved by flowing $\mathrm{CH}_{4}(10 \%) / \mathrm{Ar}$ through a water saturator working at $65^{\circ} \mathrm{C}$ and then introduced in the reactor at a flow rate of $1.2 \mathrm{~L} / \mathrm{h}$. Before each run, the effluent passed through a water-trap at $0^{\circ} \mathrm{C}$ to remove water. The gas composition was analyzed by TCD chromatograph (Hewlett-Packard 5730) containing two $2 \mathrm{~m}$ carbosieve B columns (1/8 inch, 100 - 200 mesh). The conversion rates and the selectivity of $\mathrm{CO}_{2}$ and $\mathrm{CO}$ were calculated from the following formulas:

Total rate of transformation:

$$
\operatorname{TTG}(\%)=\frac{n_{\mathrm{CH}_{4}}(\text { transformé })}{n_{\mathrm{CH}_{4}}(\text { total })} \times 100
$$

Rate of transformation in compound "i":

$$
\operatorname{TTi}(\%)=\frac{n_{i}}{n_{\mathrm{CH}_{4}}} \times 100
$$

Selectivity in compound "i":

$$
S_{i}(\%)=\frac{n_{i}}{n_{\mathrm{CH}_{4}}(\text { transformé })} \times 100=\frac{T T_{i}}{T T G} \times 100
$$

with:

$i$ : $\mathrm{CO}, \mathrm{CO}_{2}$.

$n_{i}$ : number of moles of compound "i".

$n_{\mathrm{CH}_{4}}$ : number of moles of methane.

\section{Results and Discussion}

\subsection{Catalytic Systems Characterization}

The studied catalytic systems are summarized in Table 1 whereas the XRD patterns after calcination are illustrated in Figure 1.

The results show that the nominal composition of the metal is very close to the theoretical one for the catalyst $4 \%$. On the contrary, the nickel percentage remains weak compared to the nominal values $(7 \%$ instead $10 \%)$.

Before reaction, the presence of $\mathrm{NiO}$ and the support are observed for all the catalysts. The results of XRD (Table 1 and Figure 1), before reaction, show $\mathrm{ZnO}$ zincite in all catalysts as well as $\mathrm{NiO}$. This result means that for the three catalysts, $\mathrm{NiO}$ is dispersed uniformly on the surface.

Even though the processes are related to extrinsic factors, a detailed understanding of the physical properties is needed for a high-quality catalyst. As expected, the XRD patterns of the preparation is mixed phase (Figure 1), the powder exhibits a good crystallinity with strong peaks corresponding to cubic NiO (JCPDS card $\mathrm{N}^{\circ} 47$ 1049) and hexagonal Wurtzite ZnO (JCPDS card $\mathrm{N}^{\circ} 36$ - 1451) structures. NiO crystallizes in the rocksalt structure and the crystallite size of $\mathrm{NiO}$, estimated from the full width at half maximum, average $30 \mathrm{~nm}$. Nanoplates with smooth surface and high crystallinity can be observed from Figure 2. 
Table 1. Characterization of the various nickel-based catalysts (before and after reaction) of $4 \% \mathrm{Ni} / \mathrm{ZnO}$ and $10 \% \mathrm{Ni} / \mathrm{ZnO}$.

\begin{tabular}{|c|c|c|c|c|c|c|}
\hline \multirow{2}{*}{ Samples } & \multirow{2}{*}{$\begin{array}{c}\mathrm{Ni} \\
\text { (\% Real weight) } \\
\% \mathrm{Ni}\end{array}$} & \multirow{2}{*}{$\begin{array}{c}\text { BET area } \\
\left(\mathrm{m}^{2} / \mathrm{g}\right)\end{array}$} & \multicolumn{4}{|c|}{ XRD results } \\
\hline & & & $\mathrm{d}^{\mathrm{a}}(\mathrm{nm}) \mathrm{NiO}$ & $\begin{array}{c}\mathrm{d}^{\mathrm{a}}(\mathrm{nm}) \\
\mathrm{Ni}\end{array}$ & before reaction & after reaction \\
\hline $\mathrm{ZnO}$ & - & 5 & - & - & $\mathrm{ZnO}$ zincite & $\mathrm{ZnO}$ zincite \\
\hline $4 \% \mathrm{Ni} / \mathrm{ZnO}$ & 4 & 2 & 30.4 & 20.5 & $\begin{array}{c}\mathrm{NiO} \\
\mathrm{ZnO} \text { zincite }\end{array}$ & $\begin{array}{c}\mathrm{Ni}^{\circ} \\
\mathrm{ZnO} \text { zincite }\end{array}$ \\
\hline $10 \% \mathrm{Ni} / \mathrm{ZnO}$ & 7 & 11 & 21.3 & 20.9 & $\begin{array}{c}\mathrm{NiO} \\
\mathrm{ZnO} \text { zincite }\end{array}$ & $\begin{array}{c}\mathrm{Ni}^{\circ} \\
\mathrm{ZnO} \text { zincite }\end{array}$ \\
\hline
\end{tabular}

${ }^{a}$ : Evaluated from the relation $(\mathrm{L}=0.9 \lambda / \beta \cos \theta)$ of the most intense $\mathrm{XRD}$ peak.

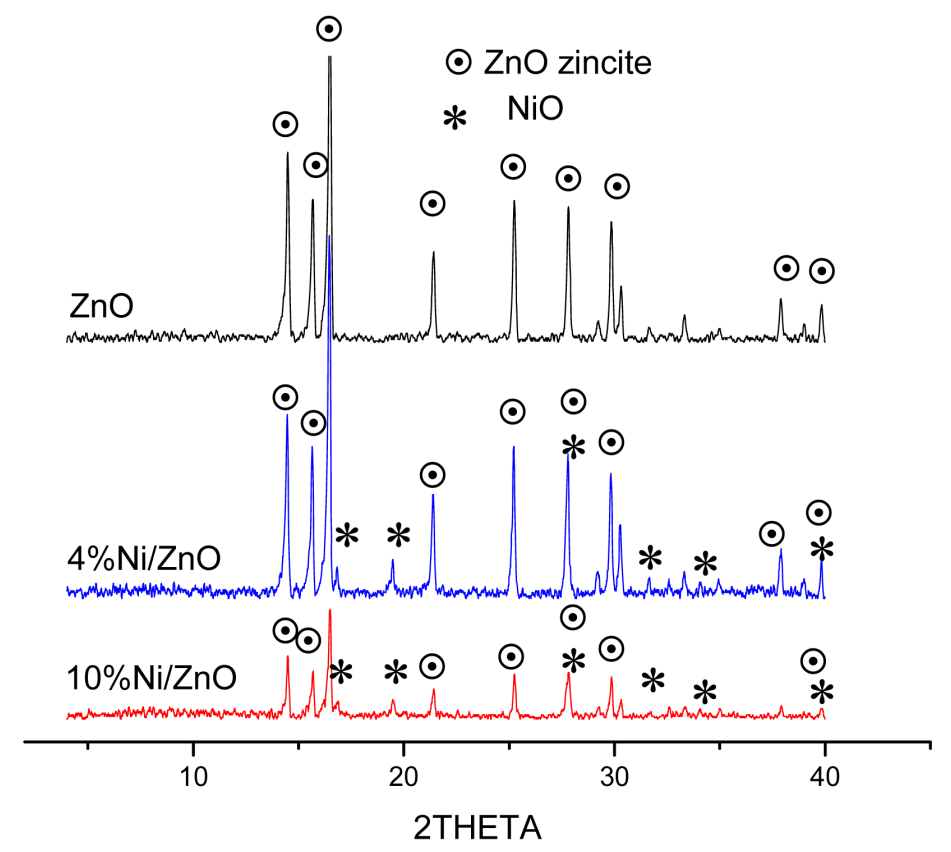

Figure 1. The patterns of support $\mathrm{ZnO}$ and catalysts, $4(\%) \mathrm{Ni} / \mathrm{OZnO}$ and $10(\%) \mathrm{NiO} / \mathrm{ZnO}$. ○: $\mathrm{ZnO}$ zincite, *: NiO.
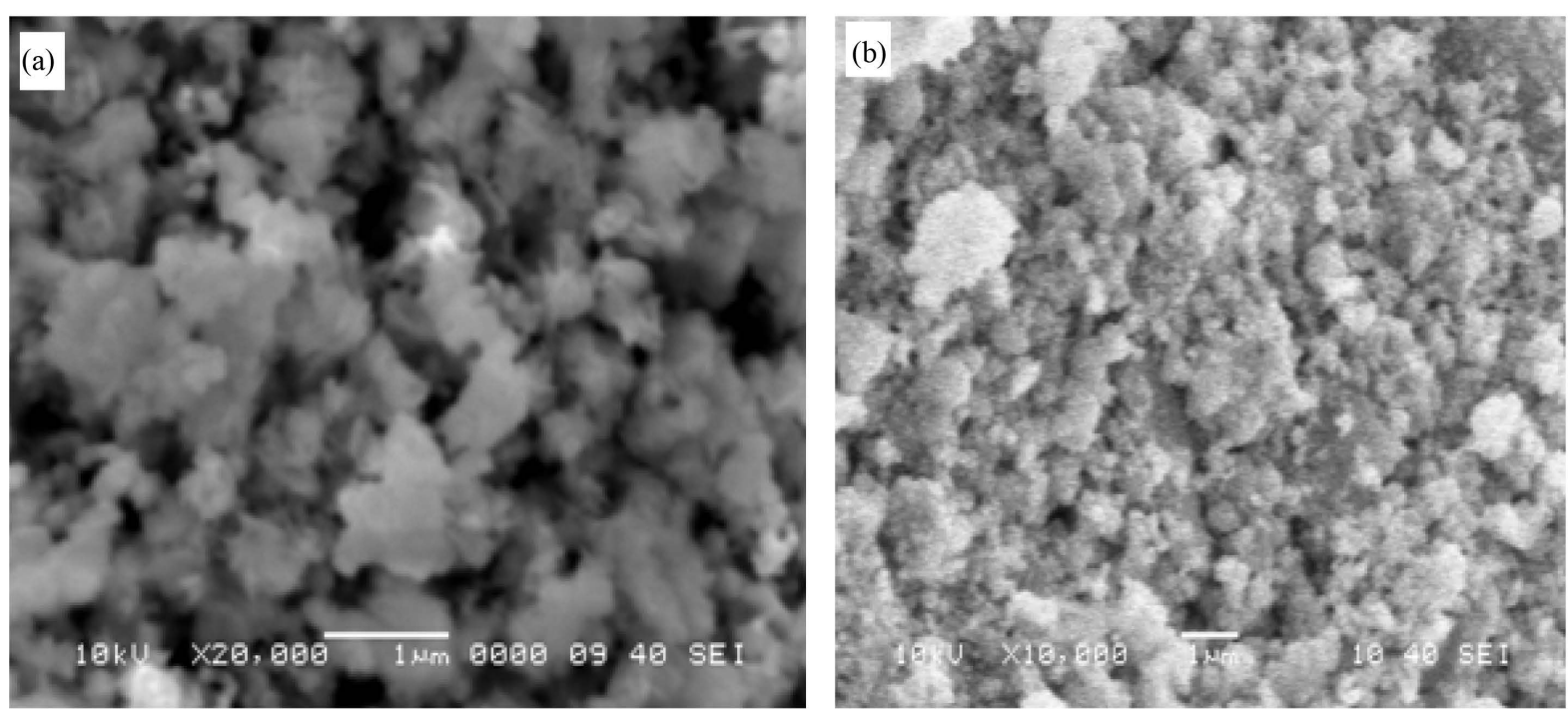

Figure 2. SEM micrograph of (a) $4 \% \mathrm{NiO} / \mathrm{ZnO}$ and (b) $10 \% \mathrm{NiO} / \mathrm{ZnO}$ elabored by impregnation after calcinations at $500^{\circ} \mathrm{C}$. 
Figure 2 shows the $\mathrm{NiO} / \mathrm{ZnO}$ hetero-system prepared by impregnation method; one observes that $\mathrm{NiO}$ nanoparticles are well-mixed with $\mathrm{ZnO}$ distributed uniformly.

The TPR profiles of the bulk nickel and $\mathrm{NiO} / \mathrm{ZnO}$ (Figure 3 ) are totally different. The reduction of $\mathrm{NiO}$ starts below $300^{\circ} \mathrm{C}$ and is completed rapidly while temperature above $460^{\circ} \mathrm{C}$ is required to reduce $\mathrm{NiO} / \mathrm{ZnO}$. The hetero-system presents one reduction peak at high temperature $\left(460^{\circ} \mathrm{C}\right)$, probably due to the reduction of $\mathrm{NiO}$ with more or less strong interaction with the support $\mathrm{ZnO}$. The reduction of $\mathrm{NiO}$ interacts weakly with the support occurs at $450^{\circ} \mathrm{C}$ [14] [15] and the calculated reduction rate reach $99.7 \%$. Ni/ZnO is well dispersed onto the support $\mathrm{ZnO}$ with no chemical bond. In addition, $\mathrm{NiO}$ exists with small crystallites uniformly spread onto the $\mathrm{ZnO}$ surface, thus leading to their facile reduction under $\mathrm{H}_{2} / \mathrm{Ar}$ flow.

The TPR profiles for the catalyst $\mathrm{Ni} / \mathrm{ZnO}$, exhibit one narrow peak with strong intensity at $460^{\circ} \mathrm{C}$ (Figure 3), in agreement with the literature. According to Jasik et al. [16], the narrow peak indicates that that the solid has a better dispersion with a good homogeneity of the active phase $\mathrm{NiO}$ over the $\mathrm{ZnO}$ support. However, the high reduction temperature implies a difficult reducibility. The temperature peak in the range $\left(300^{\circ} \mathrm{C}-500^{\circ} \mathrm{C}\right)$ has been assigned to $\mathrm{NiO}$ reduction [17]; the $\mathrm{NiO}$ reduction peak around $350^{\circ} \mathrm{C}$ agrees with the literature [18].

\subsection{Catalytic Activity}

\subsubsection{Variation of the Catalytic Activity over the Reaction Time}

The methane conversion shows that a stationary regime is reached after $\sim 3 \mathrm{~h}$, whatever the employed catalyst and Figure 4 illustrates this phenomenon for $4 \% \mathrm{Ni} / \mathrm{ZnO}$. The setting in mode is accompanied by the $\mathrm{CO}_{2}$ formation which strongly decreases as the stationary regime settles with the profit of the CO formation. This indicates an incomplete reduction of catalysts during the pre-treatment under $\mathrm{H}_{2}$ atmosphere $\left(500^{\circ} \mathrm{C}\right)$ and consequently the reaction mixture produces reduced species on the surface [19]. The carbon balance (\%) at the output of the reactor, established in the temperature range $\left(475^{\circ} \mathrm{C}-650^{\circ} \mathrm{C}\right)$ for the MSR reaction is gathered in Table 2. We noticed that the catalyst containing zinc gave less coke.

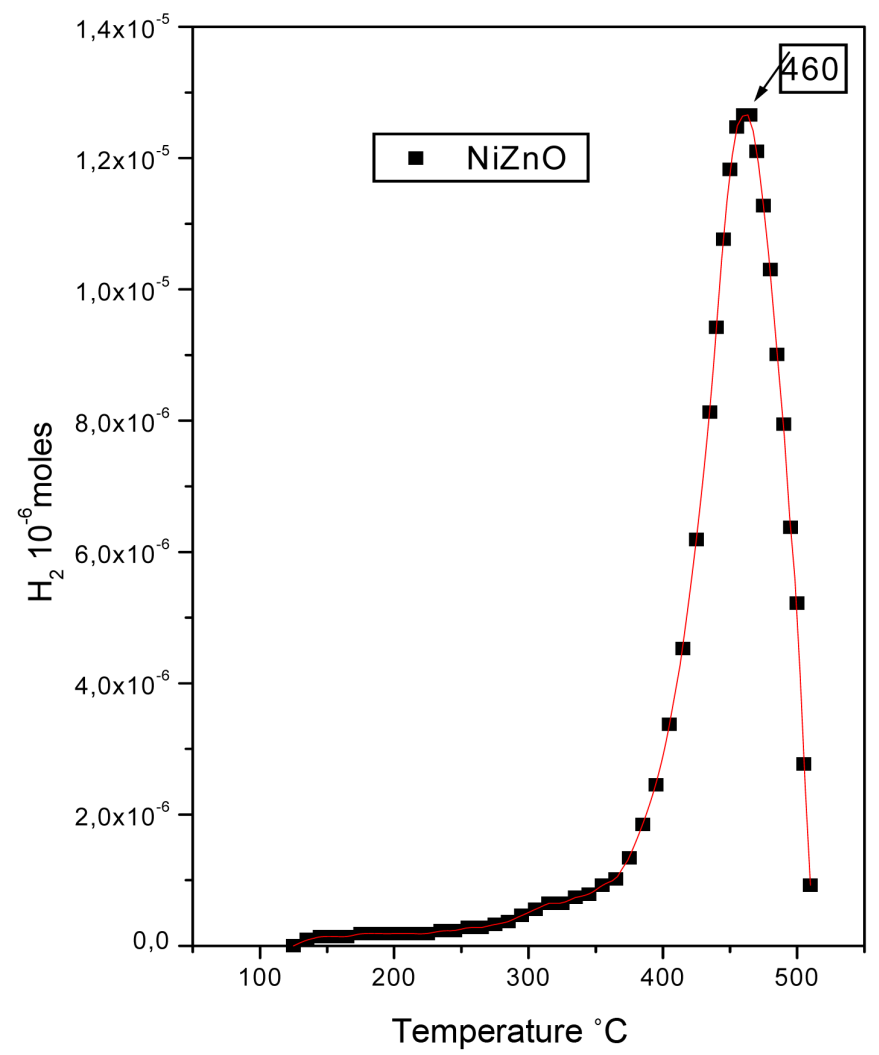

Figure 3. TPR profile of finely dispersed $4 \% \mathrm{NiO} / \mathrm{ZnO}$ powder elabored by impregnation after calcinations at $500^{\circ} \mathrm{C}$. 


\subsubsection{Effect of Nickel Percentage}

Figure 5 shows the evolution of the methane conversion as a function of the reaction temperature; the results clearly indicate that the conversion increases with raising temperature. It appears that the best conversions are those obtained with the catalyst $4 \% \mathrm{Ni}$ while the higher percentage of hydrogen is obtained on the catalyst catalyst 10\% Ni (Figure 6). These results, which vary from one catalyst to another, appear to depend not only on the interaction between nickel and support, but also on the state of dispersion of the nickel on the area of different catalysts.

It is clear from Table 2, that the CO conversion is comparable for the two catalysts. The solid which produces less coke is the one that gives the best production of hydrogen $(10 \% \mathrm{NiO} / \mathrm{ZnO})[20]$.

Table 2. Catalytic performance of the $\mathrm{NiO}$ based catalysts at $650^{\circ} \mathrm{C}$.

\begin{tabular}{ccccc}
\hline Catalyst & $\begin{array}{c}\text { Selectivity CO } \\
(\%)\end{array}$ & $\begin{array}{c}\text { Selectivity } \mathrm{CO}_{2} \\
(\%)\end{array}$ & $\% \mathrm{C}$ & $\begin{array}{c}\mathrm{H}_{2} 10^{-3} \\
(\mathrm{~mol} / \mathrm{g} \cdot \mathrm{h})\end{array}$ \\
\hline $4 \% \mathrm{Ni} / \mathrm{ZnO}$ & 62 & 23.0 & 15.4 & 8.50 \\
$10 \% \mathrm{Ni} / \mathrm{ZnO}$ & 60 & 40.0 & 0 & 25.00 \\
\hline
\end{tabular}

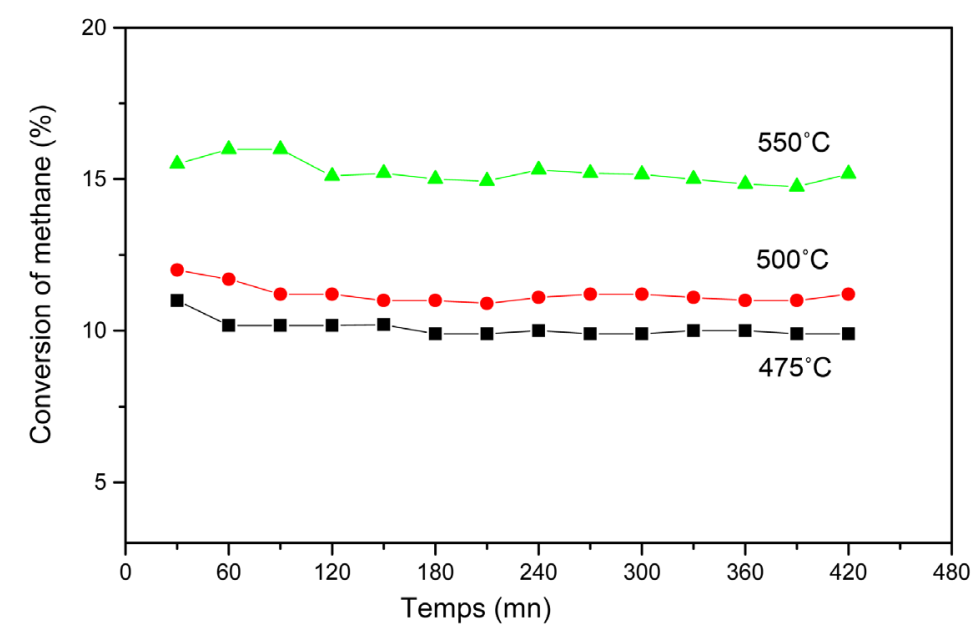

Figure 4. Methane conversion vs. reaction time for $4 \% \mathrm{Ni} / \mathrm{ZnO}$ catalyst at different temperatures; $\mathrm{m}=0.1 \mathrm{~g}, \mathrm{~T}_{\text {red }}=500^{\circ} \mathrm{C}, \mathrm{d}=1.2 \mathrm{~L} / \mathrm{h}, \mathrm{H}_{2} \mathrm{O} / \mathrm{CH}_{4}=3.3$.

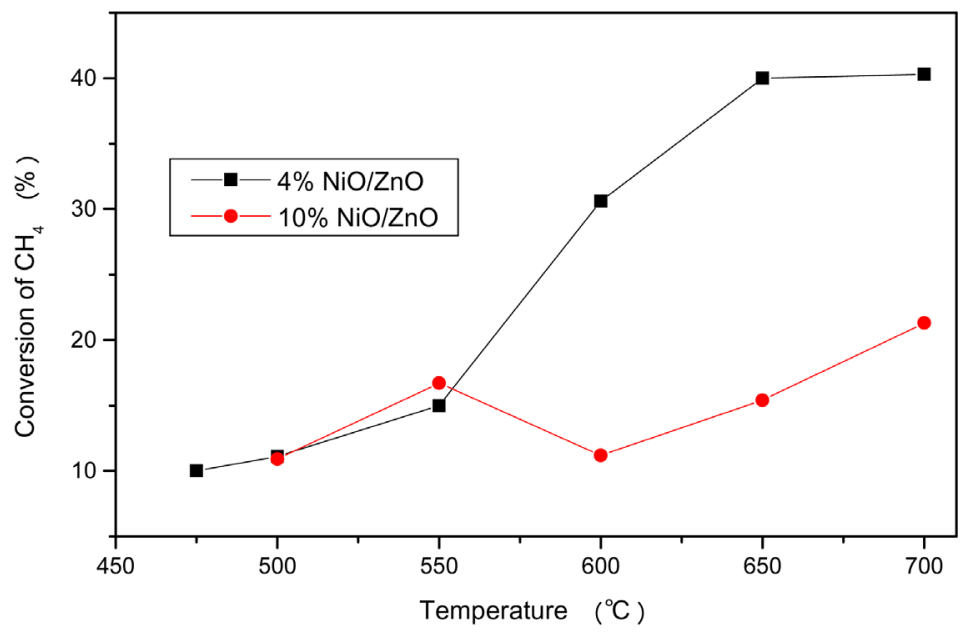

Figure 5. Methane conversion versus temperature for nickel-based catalysts $4 \%$ and $10 \% \mathrm{NiO} / \mathrm{ZnO}, \mathrm{m}=0.1 \mathrm{~g}, \mathrm{~T}_{\text {red }}=500^{\circ} \mathrm{C}, \mathrm{d}=1.2 \mathrm{~L} / \mathrm{h}, \mathrm{H}_{2} \mathrm{O} / \mathrm{CH}_{4}=3.3$. 


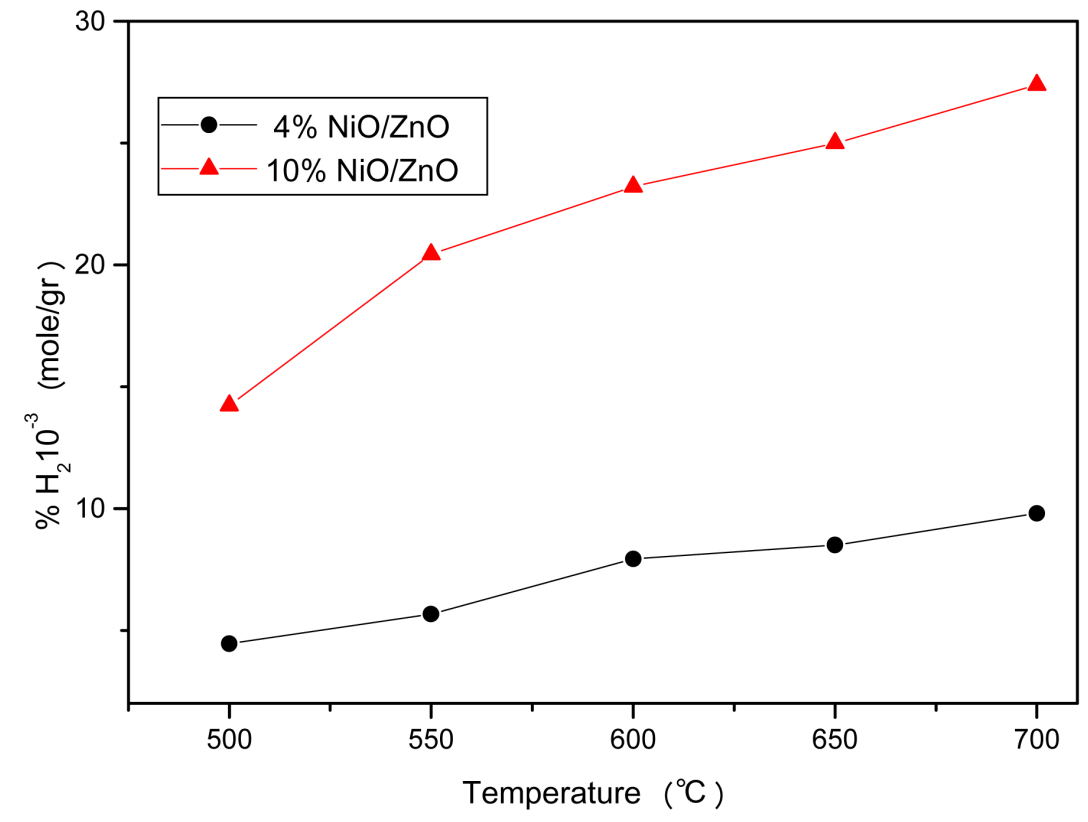

Figure 6. Production of hydrogen as a function of temperature on the nickel-based catalysts, $\mathrm{m}=0.1 \mathrm{~g}, \mathrm{~T}_{\text {red }}=500^{\circ} \mathrm{C}, \mathrm{D}=1.2 \mathrm{~L} / \mathrm{h}, \mathrm{H}_{2} \mathrm{O} / \mathrm{CH}_{4}=3.3$.

The $\mathrm{Ni}_{\mathrm{x}} / \mathrm{ZnO}$ catalytic system showed, during the MSR reaction, that the $\mathrm{H}_{2}$ evolution was directly related to the activity, the latter decreases with decreasing the particle size and decreasing also with time on stream.

\section{Conclusion}

The tests of the steam reforming of methane were performed at $650^{\circ} \mathrm{C}$ under atmospheric pressure. The results have shown that the catalytic activity in the steam methane reforming is strongly dependent on the percentage of nickel. These results appear to depend not only on the interaction between the nickel and the support, but also on the state of dispersion of nickel on the surface. Good production of hydrogen is observed over the catalyst at $10 \% \mathrm{NiO} / \mathrm{ZnO}$.

\section{References}

[1] Collodi, G. and Wheeler, F. (2010) Hydrogen Production via Steam Reforming with CO2 Capture. Chemical Engineering Transactions, 19, 37-42.

[2] Lemonidou, A.A. and Vasalos, I.A. (2002) Carbon Dioxide Reforming of Methane over 5 wt.\% Ni/CaO- $\mathrm{Al}_{2} \mathrm{O}_{3}$ Catalyst. Applied Catalysis A: General, 228, 227-235. http://dx.doi.org/10.1016/S0926-860X(01)00974-7

[3] Nagaoka, K., Takanabe, K. and Aika, K. (2002) Influence of the Phase Composition of Titania on Catalytic Behavior of $\mathrm{Co} / \mathrm{TiO} 2$ for the Dry Reforming of Methane. Chemical Communications, 2002, 1006-1007. http://dx.doi.org/10.1039/b201717m

[4] Wei, J. and Iglesia, E. (2004) Isotopic and Kinetic Assessment of the Mechanism of Methane Reforming and Decomposition Reactions on Supported Iridium Catalysts. Physical Chemistry Chemical Physics, 13, 3754-3759. http://dx.doi.org/10.1039/b400934g

[5] Rostrup-Nielsen. (2004) JR. Catal. Rev, 247-270.

[6] Zhai, X.L., Cheng, Y.H., Zhang, Z.T., Jin, Y. and Cheng, Y. (2011) Steam Reforming of Methane over Ni Catalyst in Micro-Channel Reactor. International Journal of Hydrogen Energy, 36, 7105-7113. http://dx.doi.org/10.1016/j.ijhydene.2011.03.065

[7] Ismagilov, Z.R., Pushkarev, V.V., Podyacheva, O.Y., Koryabkina, N.A. and Veringa, H.A. (2001) A Catalytic Heat-Exchanging Tubular Reactor for Combining of High Temperature Exothermic and Endothermic Reactions. Chemical Engineering Journal, 82, 355-360. http://dx.doi.org/10.1016/S1385-8947(00)00349-1

[8] Maschmeyer, T. (1998) Derivatised Mesoporous Solids. Current Opinion in Solid State and Materials Science, 3, 71- 
78. http://dx.doi.org/10.1016/S1359-0286(98)80068-5

[9] Lancaster, T.M., Lee, S.S. and Ying, J.Y. (2005) Effect of Surface Modification on the Reactivity of MCF-Supported IndaBOX. Chemical Communications, 28, 3577-3579. http://dx.doi.org/10.1039/b506205e

[10] Ortiz, M., de Diego, L.F., Abad, A., Garcia-Labiano, F., Gayan, P. and Adanez, J. (2012) Catalytic Activity of NiBased Oxygen-Carriers for Steam Methane Reforming in Chemical-Looping Processes. Energy \& Fuels, 26, 791-800. http://dx.doi.org/10.1021/ef2013612

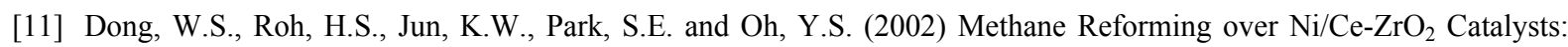
Effect of Nickel Content. Applied Catalysis A: General, 226, 63-72. http://dx.doi.org/10.1016/S0926-860X(01)00883-3

[12] Pistonesi, C., Juan, A., Irigoyen, B. and Amadeo, N. (2007) Theoretical and Experimental Study of Methane Steam Reforming Reactions over Nickel Catalyst. Applied Surface Science, 253, 4427-4437. http://dx.doi.org/10.1016/j.apsusc.2006.09.054

[13] Liu, C.J., Ye, J.Y., Jiang, J.J. and Pan, Y.X. (2011) Progresses in the Preparation of Coke Resistant Ni-based Catalyst for Steam and $\mathrm{CO}_{2}$ Reforming of Methane. ChemCatChem, 3, 529-541. http://dx.doi.org/10.1002/cctc.201000358

[14] Belhadi, A. and Cherifi, O. (2009) Effect of Ni Catalysts and Ni Promoted by Metals on Silica Toward the Reaction of Steam Reforming of Methane to Syngas. Journal of the Algerian Chemical Society, 19, 49-61.

[15] Maluf, S.S. and Assaf, E.M. (2009) Ni Catalysts with Mo Promoter for Methane Steam Reforming. Fuel, 88, 15471553. http://dx.doi.org/10.1016/j.fuel.2009.03.025

[16] Jasik, A., Wojcieszak, R., Monteverdi, S., Ziolek, M. and Bettahar, M.M. (2005) Study of Nickel Catalysts Supported on $\mathrm{Al}_{2} \mathrm{O}_{3}, \mathrm{SiO}_{2}$ or $\mathrm{Nb}_{2} \mathrm{O}_{5}$ Oxides. Journal of Molecular Catalysis A: Chemical, 242, 81-90. http://dx.doi.org/10.1016/j.molcata.2005.07.013

[17] Joo, O.S. and Jung, K.D. (2002) $\mathrm{CH}_{4}$ Dry Reforming on Alumina-Supported Nickel Catalyst. Bulletin of the Korean Chemical Society, 23, 1149-1153. http://dx.doi.org/10.5012/bkcs.2002.23.8.1149

[18] Shan, W., Luo, M., Ying, P., Shen, W. and Li, C. (2003) Reduction Property and Catalytic Activity of $\mathrm{Ce}_{1-X} \mathrm{Ni}_{X} \mathrm{O}_{2}$ Mixed Oxide Catalysts for $\mathrm{CH}_{4}$ Oxidation. Applied Catalysis A: General, 246, 1-9. http://dx.doi.org/10.1016/S0926-860X(02)00659-2

[19] Wei, J. and Iglesia, E. (2004) Isotopic and Kinetic Assessment of the Mechanism of Reactions of $\mathrm{CH}_{4}$ with $\mathrm{CO}_{2}$ or $\mathrm{H}_{2} \mathrm{O}$ to Form Synthesis Gas and Carbon on Nickel Catalysts. Journal of Catalysis, 224, 370-383. http://dx.doi.org/10.1016/j.jcat.2004.02.032

[20] Belhadi, A., Trari, M., Rabia, C. and Cherifi, O. (2013) Methane Steam Reforming on Supported Nickel Based Catalysts. Effect of Oxide $\mathrm{ZrO}_{2}, \mathrm{La}_{2} \mathrm{O}_{3}$ and Nickel Composition. Open Journal of Physical Chemistry, 3, 89-96. 